\title{
Cloud Nine on Page and Stage: A Case Study of International Adaptability
}

\author{
Johanna E. SzÉKelYhidi \\ szejohanna@gmail.com
}

\begin{abstract}
Caryl Churchill's Cloud Nine (1979) is regarded as a contemporary classic of British theatre. The play's formal innovation and revolutionary approach to gender and (post-)colonialism has been analysed thoroughly and often. However, several critics question Cloud Nine's relevance and adaptability today. This case study aims to demonstrate how the European theatrical tradition mixed with original methods helped a Hungarian theatre group, K.V. Company adapt Cloud Nine to a contemporary European stage. The analysed performance is a testimony to Cloud Nine's lasting relevance and international adaptability.

Keywords: contemporary British theatre, Caryl Churchill, Cloud Nine, performance analysis
\end{abstract}

\section{Cloud Nine on Page}

The 1970s was a decade of political playwriting in alternative British theatre. Feminism and socialism were popular points of thematic interest. Established fringe venues and experimental performance groups alike aimed to push the boundaries of theatrical expression that would suit these topics. Cloud Nine, developed near the end of the decade between 1978-79, is in many ways a typical 1970s play. However, it not only reflects the era of its creation, but points towards new, exciting forms of theatre. In the name of democratic artistic collaboration, Caryl Churchill joined the Joint Stock Theatre Group in a three-week workshop on sexual politics, where she, along with director Max Stafford-Clark, could work closely with actors from diverse sexual backgrounds. Geraldine Cousin describes the group's methodology as going "from the inside to outwards" $(1989,38)$, sharing personal experiences to discover larger patterns. They used improvisations techniques on stereotypes (Itzin 1980, 286) and status games (Cousin 1989, 38) to explore the topics of sex, politics and power. During the workshops, Churchill noticed that a common theme seemed to emerge: "the parallel between sexual and colonial oppression" $(1985,245)$, which became the main theme of the play. "For the first time I brought together two preoccupations of mine," she is quoted saying by Catherine Itzin, "people's internal states of being and the external 
political structures which affect them, which make them insane" $(1980,287)$. The workshop method allowed her to experiment with new forms of playwriting.

The play has a diptych structure (Gobert 2014, 85): it is "divided into two dissimilar units" (Cousin 1989, 39). The first half is set in colonial Africa, focusing on a British family who have thoroughly internalised the sexual repression their stereotypically sexist Victorian society preaches. It propels them to engage in an absurd and shocking variety of sexual relationships with each other, friends, and visitors. "The first [act] is [...] fast-moving, and tightly structured, with clear, boldly-drawn characters," Cousin observes. "The second half at first seems to be from a different play" $(1989,39)$. Act Two is set in 1979 London; but for the family, only twenty-five years passed. The children are all grown up, but they are just as unhappy as their parents were. The freedom sexual liberation promises seems unachievable as Victorian and colonial attitudes linger on. The family still have not reached "cloud nine," i.e. the state of perfect happiness, but now they at least have the means to pursue it, and the play ends on a potentially hopeful note as Betty, the mother, embraces her past self after finding her sexual and personal independence.

Cloud Nine was written in an era of rapid cultural change, when new conceptions of history emerged: following the cultural turn of the early 1970s, the focus shifted to microhistories instead of grand narratives (Fischer-Lichte 2014, 73). History was no longer "a list of turning points," but "an endless process" (Fischer-Lichte $2014,75)$, the story of which is told in the unheard voices of everyday people. Churchill keeps returning to this idea with plays such as Vinegar Tom (1976), Light Shining in Buckinghamshire (1976), Top Girls (1982), Fen (1983) Mad Forest (1990) or This is a Chair (1999), where history is presented as a series of small actions by everyday, often marginalized people both affected by their time and shaping it. In Cloud Nine, Clive, the head of the family is the "controlling agent" (Cousin 1989, 39) of Act One: "the society it shows [...] is male-dominated and firmly structured. In Act Two, more energy comes from the women and the gays" (Churchill 1985, 246). Clive only returns as a ghost in Act Two, representing the heritage of patriarchy and colonialism which will take a while to exorcise, but he is rendered powerless as Betty, his wife, starts realizing her own power. He is no longer in the narrative focus, and history is told by and shaped through his sexually independent wife, queer son and bisexual daughter.

In both acts, the family is presented as a "unit of power relations" (Gobert 2014, 87) with "competing hierarchies of gender [...], rank, occupation, [and] age" (Gobert 2014, 95). As Darren Gobert points out, in Act One, these hierarchies are 
kept intact through "discipline and punish" $(204,86) .{ }^{1}$ Any sort of transgression is met with retribution, either through internalised discipline and self-control (Edward [to his father]: "I was playing with Vicky's doll again and I know it's wicked of me [...] please beat me and forgive me" [Churchill 1985, 276]), or external forces (in the form of a (grand)motherly slap). However, "discipline and punish" are revealed to be ineffective: while punishment follows minor transgressions, actual sins do not end in reckoning. The family's friend, Harry, takes sexual advantage of the underage Edward, which is never discovered despite the warning signs. Clive punishes Betty for trying to elope with Harry, but the fact that Clive is cheating on her with their neighbour, Mrs. Sanders, never has any consequence for him, and in the end he banishes his lover, blaming that she was the one who initiated the kiss Betty witnesses. The lack of ethically motivated punishment, as well as the comedic framing of the events challenge the idea of "discipline and punish" as a device that is actually capable of upholding the competing hierarchies.

Indeed, Act Two shows the collapse of hierarchy based on gender, rank, occupation, or age. At the end Betty finds fulfilment as a senior, and her children, initially irritated by the helplessness of their aging mother, learn to accept her. Although Edward seems ashamed of his occupation as a gardener, and there is tension between the working-class Liv and her partner, the bourgeois intellectual Vicky, due to their status (Reinelt 1985, 52), the gap can be bridged despite occupation or rank, and the three of them end up in a relationship, living together as equals. Examining the gender roles in Act Two, Paola Botham observes that the contested gender role of "wife" seems to connect all main characters: "[r]eiterating the commentary on marriage from Act One, the struggle of Lin (Cathy's mother), Victoria, Edward and Betty in Act Two can be summarised as a moving away from this given role in order to find autonomy, sexual fulfilment and more rewarding relationships" (Botham 2012, 119). However, despite these achievements, the cycle of patriarchy and colonialism is not yet broken. As Reinelt points out, "[w] hile Victorian sex-role stereotyping and political chauvinism were deadly [in Act One], contemporary role confusion and the residue of imperialism remain problematic [in Act Two]" (Reinelt 1985, 51). The confusion of gender roles will be discussed in detail in part II as I analyse how Ördög's production (2017) reflects on the theoretical questions raised by the playtext.

Before concluding this short overview of Cloud Nine, I want to comment on the "residue of imperialism" (Reinelt 1985, 51). As Botham points out, critics of the play expressed the concern that Cloud Nine did not effectively challenge colonialism

Gobert is following Michel Foucault's famous theories outlined in Discipline and Punish: The Birth of the Prison [Surveiller et punir: naissance de la prison] (New York: Pantheon Books, 1977). 
(2012, 120), as setting up a parallel between sexual oppression and imperialism might not be enough. Joshua, Clive's black servant, disappears from the play by Act Two, thus his narrative is broken and unresolved, unlike the white characters' story arcs. Doubling could be a saving grace, but since Joshua is played by a white actor, ${ }^{2}$ this device cannot be used effectively to give resolution to his story (Gobert 2014, 98). Even though Act One ends with the powerful image of the loyal Joshua finally picking up a rifle and pointing it at his master, Clive, Act Two implies that Clive has survived the incident, and therefore this act of rebellion seems to have been effectively pointless. However, it can be argued that imperialism is still directly addressed in Act Two: in the middle of the orgy scene between Edward, Vicky and Lin, Lin's brother appears as a ghost, and we learn that he was a British soldier who died fighting in Northern Ireland. The ethno-nationalist armed conflict of The Troubles, and Britain's military involvement can doubtlessly be linked to imperial attitudes. The soldier's appearance seems to open a portal to other ghosts, as Clive, Edward, Maudy, Ellen, Harry and Betty from Act One re-appear shortly after his introduction. The British soldier quite literally brings colonial shadows with him, whose hauntings are all connected to sexuality and shame, uniting the focal points of colonial and sexual oppression. This nuanced structural trick may be easily lost in adaptation. Interestingly, the soldier was cut from Ördög's production, probably due to the fact that Hungarian audiences might not be familiar with the Northern Ireland conflict, and Hungary does not share Britain's colonialist history. However, with this cut, the re-appearance of the other ghosts was dropped, too, and thus Act Two does not reflect on colonialism at all, leaving Act One even more unresolved than in the original playtext. This raises the question whether the play is readily adaptable to European stages. Hungarian critic Natália Kovács argues that Cloud Nine is an essentially "British" play (regarding historical references, stereotypical characters, humour and politics), therefore a Hungarian audience is unable to fully relate to it, which decreases the play's emotional impact; she criticised Ördög's production for making no attempt to give it a Hungarian flavour (Kovács, 2017).

Another concern often mentioned in regard to the play's local and international reception is the criticism that Act Two, with its 1979 setting, is outdated (Botham 2012, 121-122), a sentiment shared by Hungarian critic Gábor Bóta (2018). Even the play's original director, Max Stafford-Clark noted after seeing a revival at the Old Vic in 1999 that "[...] the second half, which at the time had been absolutely contemporary, seems, twenty years later, to have become just as quaint and historical as the Victorian sex mores in the first half. So you thought, how

Joshua's cross-racial casting is to illustrate that "he wants to be what whites want him to be" (Churchill 1985, 245). 
extraordinary that we all felt that at the moment and she captured it absolutely" (qtd. in Little and McLaughlin 2007, 195). However, Botham points out that the "machismo-in-disguise" attitudes in Act Two "serve as a warning for those who believe the age of post-feminism has arrived," 3 and regards the piece to be a "relevant classic" (2012, 122).

These concerns will be examined in detail regarding Ördög's production, focusing on the following questions: is the play adaptable to a non-British stage? Is it still relevant?

\section{Cloud Nine on the Hungarian Stage}

Ördög's production is a somewhat unique adaptation of Caryl Churchill's work in a Hungarian context. Although Churchill has been an internationally recognised contemporary playwright since the 1970s, her fame did not quite reach Hungary until 1993, when Mad Forest, directed by László Bagossy Sr., premiered at Kis Theatre, Pécs (Kurdi 2015). Hungarian audiences had to wait nearly a decade to see another Churchill production: The Skriker debuted in 2000 (dir. Sándor Zsótér, Víg Theatre, Budapest) and was revived in a new production in a collaboration of puppet and regular theatres in 2013 (dir. Gábor Tengely, Katona Theatre and Budapest Puppet Theatre, Budapest); Far Away and A Number premiered in 2005 (dir. Balázs Simon, Millenáris Theatre Company, Budapest), and the latter was revived in 2006 (dir. Edina Szántai, RS9 Theatre Company, Budapest); a student production of Vinegar Tom followed in 2015, directed by Natália Pikli and performed by the Ducking Witches Theatre Company at the 7th Veszprém English-Speaking Theatre Festival (Kurdi 2015).

Mária Kurdi points out that K.V. Company have a special interest in presenting Caryl Churchill on Hungarian stages: in 2008, they did a staged reading of Blue Heart (dir. Attila Grigor, MU Theatre), followed by a 2009 staged reading of Cloud Nine (dir. Pál Göttinger), which developed into a live performance, premiering in 2017 (Kurdi 2015). The 2017 production was directed by Ördög Tamás and premiered in Trafó House of Contemporary Arts, a popular independent venue in the heart of Budapest; the ensemble cast was invited by K.V. Company. ${ }^{4}$ This section will analyse

\footnotetext{
Note that following the \#MeToo movement, where Stafford-Clarck was ousted for sexual harassment by The Guardian, his credibility regarding sensitivity to women's rights and feminism came into question.

4 The full cast was as follows: Zsuzsanna Száger (Mrs. Saunders/Lin) and Krisztina Ubranovits (Ellen/ Betty) from KV Company; Sándor Terhes (Harry/Martin) from Krétakör; Zoltán Schmied (Clive/Cathy) from Central Theatre; Zoltán Szabó (Betty/Edward) from Pintér Béla and Company; independent actor Gábor Jászberényi (Joshua/Gerry); actor in training Emina Messaudi (Edward/Vicky).
} 
this performance in detail to see whether Cloud Nine is adaptable to a European stage, and whether it is still relevant in the late 2010s. I will pay special attention to Brechtian and Grotowskian theatrical traditions, which significantly influenced the production, to argue that these traditional devices along the unique innovations of Ördög and K.V. Company made the play not only perfectly digestible to a Hungarian audience despite the reviewers' criticism, but also offered a contemporary, refreshing take on the play.

Cloud Nine was not performed on the main stage of Trafó House of Contemporary Arts, but downstairs, in the basement. Using a smaller space for the performance contributed to a forced familiarity between spectators and actors. The actors were waiting for the spectators in costume, playing their roles wordlessly in a tableau vivant. The members of the audience had to cross the playing area, thus entering the actor's sphere if they wanted to take their seat in the second row of chairs (see fig. 1).

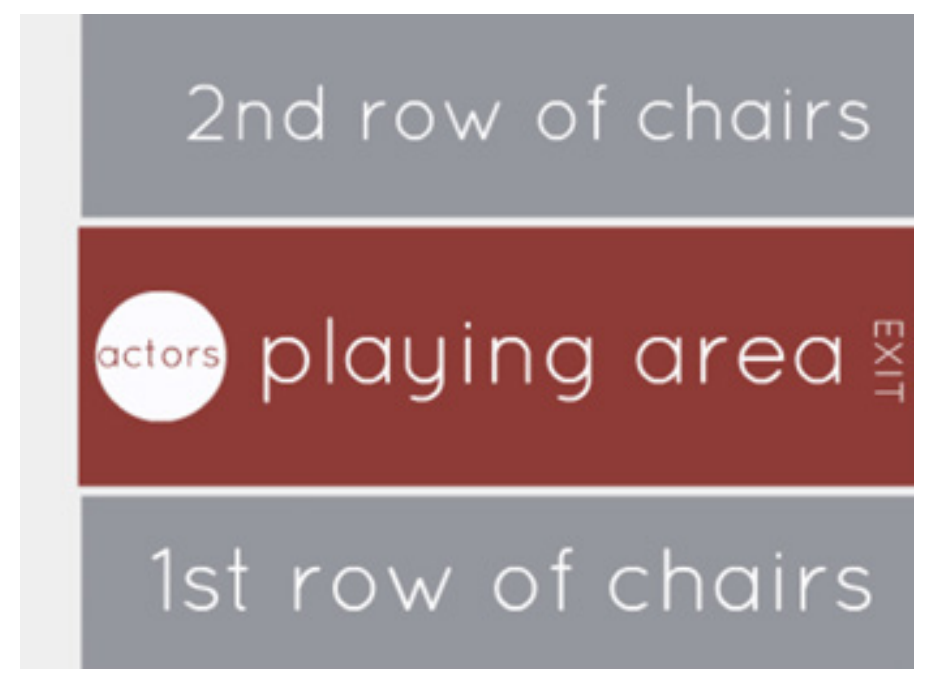

Fig. 1. Seating arrangement in K.V. Company's Cloud Nine

(the author's illustration)

This elimination of the elevated stage can be linked to Jerzy Grotowski's poor theatre, a performance style which aimed to remove everything that was not essential for theatre. Theatre, in Grotowski's terms, is the interaction between actor and spectator, a "direct connection between living human beings" $(1999,30) .^{5}$ Therefore, removing the stage removes a barrier between them. Once actors and spectators are literally on the same level, one can begin to experiment with seating arrangements to draw back the "psychological curtain" separating them (Grotowski

5 Translations from Hungarian sources here and in the rest of the article are my own. 
qtd. in Kékesi Kun 2007, 256). His collaboration with architect Jerzy Gurawski inspired Grotowski to re-arrange seating before each individual performance and see how it affects the spectators' reactions. (Grotowski 1999, 57). Cloud Nine did not go this far: while the seating arrangement was unconventional, it remained the same with each new performance. However, the arrangement reminds one of Grotowski and Gurawski's Sakuntalá (see fig. 2), and used the same mirroring effect: once seated, one group of spectators was facing the other, and thus made to confront their fellow spectators, not just the actors.

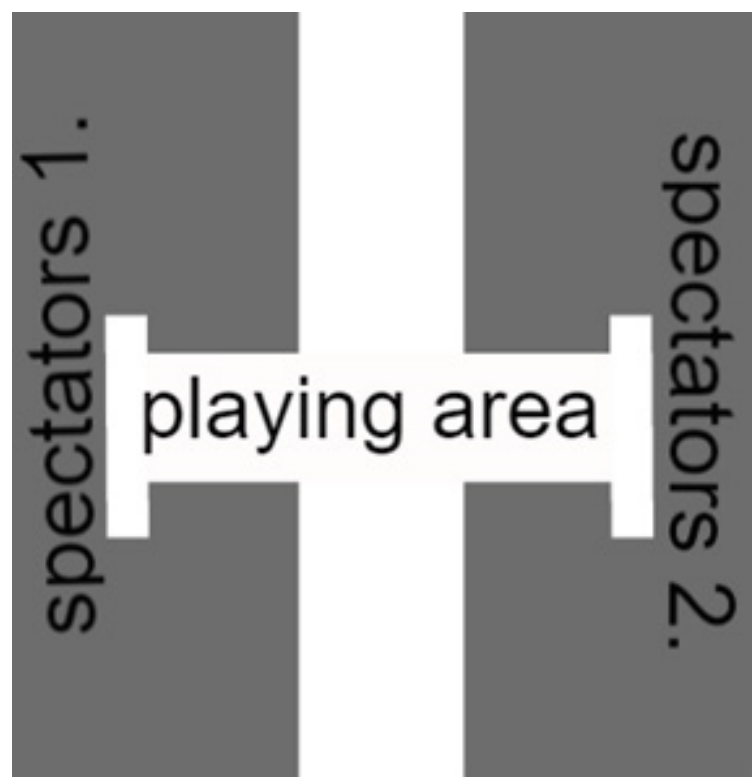

Fig. 2. Seating arrangement in Grotowski’s Sakuntalá

(the author's illustration based on Árpád Kékesi Kun, A rendezés színháza [Budapest: Osiris, 2007], 524)

I believe that the small venue, the removal of an elevated stage, and the mirrored seating arrangement were fundamental devices to successfully adapt Cloud Nine for a contemporary Hungarian audience. Neither Grotowski nor Bertolt Brecht's practice or theories deal much with the unique connection that forms between the individual members of an audience removed from the usual position: both directors tended to treat the audience as a homogenous unit, and seemed to expect their reactions to the play to be rather uniform. This static understanding of the audience as a collection of witnesses (Grotowski), or a collection of critical viewers (Brecht) had still been innovative and shaped the way we look at European theatre. Zoltán Imre points out that usually, the audience is expected to behave as if they were simply not present: even though they may laugh at the jokes and are expected to clap at the end, otherwise the spectators need to be invisible and bodiless 
(Imre 2003, 89). Just making the audience visible and accounting for their bodily presence is a significant step towards accounting for spectator/spectator relations.

The Ördög and K.V. Company production proved that the audience's emotional responses are far from uniform. For example, in the scene where the lesbian governess Ellen is made to marry the predatory and queer Harry, crying her heart out and holding a knife to cut the wedding cake or stab him, some members of the audience were shaking with laughter, others had a look of sympathy; there was shock on some faces, horror on others, nervous anticipation, even boredom or disinterest. Audiences will never react in the same way, and Ördög and K.V. Company highlighted this by using traditional theatrical techniques borrowed from Grotowski and Brecht. However, they foregrounded the critical provocation of actor and audience confrontation by encouraging audience and audience confrontation: our viewing experience was influenced by how other spectators reacted to the play. Furthermore, a contemporary Hungarian audience was physically inserted into the narrative of Cloud Nine: not just as backdrop, but participants through intensified emotional involvement and being put on display in an evenly lit theatrical space.

The performance took place under white lights, one of Brecht's signature visual signs (Fuegi 1994, 168). In his theory, the function of the unchanging white lights was to illuminate truth: "[t]his [white light] gave his productions tremendous visual clarity, in which everything was held up for analysis, like a body on a dissecting table" (Unwin, 2005). In Ördög and K.V. Company's production, the internal truth of Cloud Nine was illuminated, pointing out how gender is performed, how oppression operates through the ages. An external truth also came into the spotlight, revealing the performance as theatrical. The refusal to use traditional mood lighting, a practice also supported by Grotowski $(1999,15)$, and to involve the audience in the spotlight, made shedding light on uncomfortable truths the central theme of the play. It highlighted the lack of distance between the revealed truth of the play and the audience's position: maybe we are not as far away from restricting gender roles and oppression as we would like to think.

The set had the function to further close this distance. In Act One, a potted plant, a plastic chair and a bamboo curtain hinted at the African scenery, but the design was deliberately minimalist and unpolished. Act Two repurposed props and set elements from Act One, or just left them lying around: Ellen's wedding veil covered a desk that was used as an altar for Vicky's troubled husband, Martin. Items were liberated from their previous roles the same way as the characters, but they, too, had the burden of heritage: the white plastic chair could not just be a chair anymore, since the audience remembered it to be Clive's "throne," and thus Betty sitting in it comfortably in Act Two and symbolically taking her husband's dominant position was a subtle, but significant visual reminder. The featureless set gave the impression that the play could 
take place anywhere, any time: not only was the jump between the Victorian and contemporary setting less of a leap, but it made the entire set more timeless and less markedly British (the playtext and most English productions involve a prominent Union Jack). ${ }^{6}$ Both Brecht's epic theatre (Kékesi Kun 2007, 170) and Grotowski's poor theatre (1999, 9-20) recognised the potential of a stage stripped of its usual overpowering visuals; however, their ideas differed about costumes.

Grotowski sought to eliminate costumes in the same fashion as he wanted to minimize the impact of setting $(1999,13)$, while Brecht believed that historically accurate costumes would serve the desired alienation effect: audiences would not identify with the characters, and gain a historical perspective on the events (Kékesi Kun 2007, 176-177). Most British productions of Cloud Nine used lavish costumes, ${ }^{7}$ but Ördög and the K.V. Company's production had a new approach. The costume design was expressly ironic in Act One: Betty, the Victorian housewife, was wearing a shirt with a monkey print, fake earrings, red lipstick, and a cheap hat. There was a hint of elegance, but it was all glamour-just as her gender was all pretence, since she was played by a male actor. ${ }^{8}$ Similarly, Clive, her husband, was dressed for a safari, but he was wearing a leather jacket, exaggerating his masculinity at the cost of historical accuracy.

Although the costumes did not follow Brecht's preferred method of historical accuracy, I believe they achieved a similar V-effect through the playfulness and humour of the costume design. The characters looked like broadly drawn caricatures; furthermore, their costumes were constant reminders that the play was merely a performance, making identification impossible. However, for Act Two, the actors changed their costumes in front of the spectators, undressing in plain sight and tossing each other items of clothing as they put on new roles. The new roles and costumes felt more authentic than the ironic costumes of Act One, even though the audience witnessed the changing process. Since they fitted the contemporary setting, and with the exception of Cathy, the characters' gender, they were neither playful nor ironic — which just served to highlight the playful irony of Act One. Act Two, through the costumes alone, made the audience reconsider their relationship to the characters and the play's reality. It felt closer to home.

Besides the ironic costumes, nakedness played a significant role in the production, as both acts featured explicit sex scenes. In Act One, Clive performed oral sex

\footnotetext{
${ }^{6}$ The Union Jack is not only part of the set design in most productions, but it is referred to in the opening song and features in Harry's magic trick; these references were also dropped from the Ördög and K.V. Company production, implying a further deliberate distancing from the play's British context without changing the play's location or the characters' nationality.

A famous and recent example would be Thea Sharrock's 2007 production at Almeida Theatre, London.

8 The purpose of the cross-gender casting is to reveal the characters' inner truth (Churchill 1985, 241-50).
} 
on his mistress in the cover of her long skirt. Although nudity was only implied by her underwear being tossed aside, the actors were embarrassingly close to the audience, and their naturalistically performed passion provoked laughter. When Clive emerged, bodily fluids were smeared over his chin, and a spot on his trousers marked his discharge. He spilled some champagne over the spot to hide it from the characters arriving at the scene. A bottle of champagne played a role in Act Two's orgy scene, where the grown-up Edward opened the bottle and sprayed it around, drank from it then spat it out in playful indulgence. He was fully naked, while the other participants of the orgy, his sister Vicky and her girlfriend Lin, were wearing underwear. The physical presence and pervading smell of the champagne connected this scene to Clive's comparatively modest sex scene. While adultery was done in secret, and the spectators were complicit witnesses, the orgy of Edward, Vicky and Lin was proudly performed in public, forcing the audience to confront several taboos (full frontal male nudity, lesbian sex, public sex, ménáge-á-trois, and incest). Grotowski argues that "breaking taboos, transgression [...] is only made possible through shock [...] undressing completely, revealing everything" (Grotowski 1999, 17). Péter P. Müller, however, is of the opinion that the taboobreaking shock value of theatrical nudity has worn off due to its frequent usage on contemporary European stages $(2019,217)$. He adds that although it might provoke embarrassment, it will never be amusing $(2019,215)$. Cloud Nine put this theory to test, since both sex acts had a comedic framing, and the orgy scene, embarrassing and arguably shocking as it was, was highly entertaining.

Comedy is an often overlooked element of Brechtian theatre: "his dramatic world would scarcely suggest a climate favourable for comedy [...]. The race of men that inhabits this world is at best, mean and exploited-at worst, viscous and predatory;" however, "laughter is one of the most frequent responses his [Brecht's] plays elicit" (Hoffmann 1963, 157). This apparent contradiction can be resolved if one considers the role laughter plays in breaking tension. It can be an effective tool to invite audiences for introspection and make them question why they are laughing. Cloud Nine utilized dark humour for a similar effect, and connected humour to provocation, making the audience laugh when they should not. The details of a paedophile's horrific acts had a comic beat, and when Ellen, the governess threatened to kill herself and cried with anguish, collapsed on the floor, the spectators laughed. The events themselves were anything but amusing: but the dialogue, the dramaturgy and the acting made it comic. Still, laughter had a bitter aftertaste: the spectators might take a moment to examine their empathy, thus uniting the role of critical witness (capable of introspection) and participants with strong emotional reactions (responses which they were invited to examine). 
However farcical the characters were, however caricaturistic, there were significant moments when the spectators felt for them. As Betty relates in Act Two how she masturbated the first time after her abusive husband's death, realising with wonder that she was perfectly capable of giving herself pleasure, a sympathetic lull washed over the audience: this part was performed as a monologue directly addressed to the spectators - the actress met the eye of the onlookers, and connected with them through the character's story. Similarly, despite the ironic humour of cross-dressing, one could not help but be charmed by the Victorian housewife Betty played by a man desperately trying to be feminine, or feel a conflicted sympathy for the paedophile Harry who could not live with his guilt, his expression tormented as he fretted with his hands. The performance refused to give up on humanity. It did not settle merely for a critical overview of human behaviour, contrasting humour with sympathy and alienation with empathy. It left conclusions up to its audience instead of settling on an unambiguous message.

It appears as if the play's critics expected Cloud Nine to be closer to our idea of Brecht's plays which are expected to have a clear, almost didactic political message, and wanted it to take a definite position on current sexual politics. The criticism that the play fails to be adaptable to a non-British audience and is not contemporary enough, connects to this misguided expectation. As David Barnett points out, the Brechtian tradition is frequently misunderstood and misrepresented: Brecht's world is "unstable and consequently changeable," his theatre "encourages spectators to pick out contradictions in society and seek new ways of reconciling them" (2015, 4-5). He does not offer clear answers. Neither does Cloud Nine. The Ördög and K.V. Company production relied on a Brechtian tradition that understands Brecht's theatre as "a fundamentally political theatre, because it asks audiences not to accept the status quo, but to appreciate that oppressive structures can be changed if the will for that exists" (Barnett 2015,3). Cloud Nine, both on stage and page, is cautious not to settle for the status quo following the sexual revolution of the 1960s-70s: if Act Two's political message seems outdated, one might be under the debatable belief that we now live in a fully emancipated society, where issues of gender roles and sexuality are fully settled. Churchill's political theatre, like Brecht's, is too subtle to rub its message in. Her work is not defined by party politics or reactionist retorts. As Pikli points out, "Churchill does not focus on propaganda theatre: she mixes viewpoints, registers and various artistic genres, which make her plays work well on stage." Churchill projects globally relevant political questions on personal relationships, seeking the key component of the human condition $(2018,83)$.

Churchill insisted that Act One should not merely be a farce, "so that we do care about them [the characters] as people" and while Act Two clearly gets more 
realistic, it "mustn't get naturalistic" (qtd. in Fitzsimmons, Trussler and Page 1989, 48). Ördög and K.V. Company's production achieved this by using Brechtian and Grotowskian methods in an innovative way, so the play had an empathic approach to its characters and established a close connection with the spectators. I would argue that through the humanity of the characters, the play does become universally adaptable and contemporary, since it reflects on the human condition beyond Victorian or 1970s English society. The close connection established with the spectators made a contemporary Hungarian audience involved in the performance and relate to it intimately. Using traditional techniques by established European directors such as Brecht and Grotowski also helped to make Cloud Nine feel more familiar, embedding it into a tradition that is recognizable to Hungarian theatre-goers. This opened the possibility to reflect on the relevance of its political message while enjoying it as a universal work of art.

\section{Works Cited}

Barnett, David. 2015. Brecht in Practice: Theatre, Theory and Performance. London: Bloomsbury. https://doi.org/10.5040/9781408183144

Botham, Paola. 2012. "Caryl Churchill." In Modern British Playwriting: The 1970s, edited by Chris Megson, London: Methuen Drama, 99-123.

Bóta Gábor. 2018. "Földi pokol.” FüḦ̈, 14 February 2018. https://fuhu.hu/foldipokol/.

Cousin, Geraldine. 1989. Churchill: The Playwright. London: Methuen.

Churchill, Caryl. 1985. Plays: One. London: Methuen.

Fitzsimmons, Linda, Simon Trussler and Malcolm Page. 1989. File on Churchill. London: Methuen.

Fischer-Lichte, Erika. 2014. The Routledge Introduction to Theatre and Performance Studies, edited by Minou Arjomand and Ramone Mosse, translated by Minou Arjomand. London: Routledge. https://doi.org/10.4324/9780203068731

Fuegi, John. 1994. Brecht and Company: Sex, Politics, and the Making of Modern Drama. New York: Grove Press.

Gobert, R. Darren. 2014. The Theatre of Caryl Churchill. London: Bloomsbury Methuen Drama. https://doi.org/10.5040/9781408166390

Grotowski, Jerzy. 1999. Szinház és rituálé: Szövegek 1965-1969, edited by Janus Degler and Zbigniew Osiński, translated by Pályi András. Budapest: Kalligram. Hoffmann, Charles W. 1963. "Brecht's Humor: Laughter While the Shark Bites." The Germanic Review: Literature, Culture, Theory. 38(2): 157-166. https://doi.org/10.1080/19306962.1963.11787129 
Imre Zoltán. 2003. Szinház és teatralitás: Néhány kortárs lehetöség. Veszprém: Veszprémi Egyetemi.

Itzin, Catherine. 1980. Stages in the Revolution: Political Theatre in Britain since 1968. London: Methuen.

Kékesi Kun Árpád. 2007. A rendezés szinháza. Budapest: Osiris.

Kovács Natália. 2017. "Túl a szövegen: Caryl Churchill - Földi Paradicsom." Kútszéli Stílus. Accessed 13 February, 2019. https://www.kutszelistilus.hu/ szinhaz/kritika/476-kovacs-natalia-tul-a-szovegen.

Kurdi Mária. 2015. "Caryl Churchill 80 éves: Churchill-bemutatók Magyarországon.” Criticai Lapok Online 7-8. Accessed 13 February, 2019. www.criticailapok.hu/2-uncategorised?start $=15$

Little, Ruth and Emily McLaughlin. 2007. The Royal Court Theatre Inside Out. London: Oberon Books.

Müller Péter P. 2009. Test és teatralitás. Budapest: Balassi.

Ördög Tamás, dir. 2017. Földi paradicsom, by Caryl Churchill. K.V. Company. 26 November 2017. Budapest: Trafó House of Contemporary Arts.

Pikli Natália. 2018. "A politikus színház és a történelmi pillanat: állandóság és romlékonyság (Caryl Churchill).” In Szinházi politika \# politikai szinház, edited by Antal Klaudia, Pandur Petra and P. Müller Péter, 78-91. Pécs: Kronosz.

Reinelt, Janelle. 1985. "Elaborating Brecht: Churchill's Domestic Drama." Communications from the International Brecht Society 14(2 (April)): 49-56.

Unwin, Stephen. 2005. A Guide to the Plays of Bertolt Brecht. London: Bloomsbury. eBook. https://doi.org/10.5040/9781408168493 